\title{
THE CONTENT OF NATURE FOUND IN WILLIAM SHAKESPEARE'S KING LEAR
}

\author{
By: Ali Fauzi
}

\begin{abstract}
Drama is a literary work in which it reflects the activities of human beings and the surrounding life. It delineates life and human activity by means of presenting various actions of-and dialogues between-a group of characters. It also uses natural mimetic in form of symbolic nature of dramatic character and looks that nature becomes a part of subject matter which is quiet close to the action of men. The background of Shakespeare's King Lear is the nature or the universe itself. Shakespeare uses the instrument of nature, the product of nature wholly and the hierarchy of the society combined with the medieval and old mythology to be the materials of his play. He uses the existence of nature to be interrelated with the parts, the naturalistic phenomena and with human beings and their life problems. The whole universe or nature is the cosmic system in which human beings form the system of social structure and live in harmony with other system where every element in the cosmos has its meaning only in relation to the other parts Therefore, it attracted Shakespeare so much to interpret the image of the cosmic system and its parts that the content of nature is richly found in the play. The content of nature consists of Cosmos including microcosm (a man, an animal-birds, a fox, an ape, an ass, wolves, a bull- a fiend and a sea monster, a Stock, a castle, a heath and hovel, clothes, music and medicine, a wheel) and macrocosm (a sun, a moon and other orbs, a storm, a rain, a thunder and lighting, an earth, an air, a fire and water, the insane, the death, the hell and the heaven).
\end{abstract}

Key Words: Content, Nature, King Lear, William Shakespeare 


\section{A. INTRODUCTION}

As literary genre, drama is a literary work in which it reflects the activities of human beings and the surrounding life. It delineates life and human activity by means of presenting various actions of-and dialogues between-a group of characters (Reaske, 1966: 5). Since drama reflects the surrounding life of human beings, it also uses natural mimetic in form of symbolic nature of dramatic character (Elizabeth and Tom burn, 1973: 285). It looks that nature becomes a part of subject matter which is quiet close to the action of men. The basic assumption is that a man, like all other creatures, is part of great order of brute nature; therefore, man's fate is to live and die not in imitation of the gods or in the style of the hero but, like every other animal, scrambling for survival and buffeted by an indifferent universe. Drama depicts its protagonist in conflict with both his fellow man and the elements of natural cruelty and has him emerge from battle with a new-found confidence in his manhood only after behaving consistently with the law of the jungle rather than the law of society (Liberman and Foster, 1968: 76). Thus, Shipley says (1962: 279) the dramatist's activity is thought of as an imitation of the creative processes of nature, and his successful achievement as a representation of the universal actions and passions of men.

As it is seen that the background of Shakespeare's King Lear is the nature or the universe itself. The whole universe was governed by divine will; nature was God's instrument, the social hierarchy a product of nature and the task of human reason is to keep the nature and to be enjoined by nature (Ford, 1960: 18-19). Shakespeare uses the instrument of nature, the product of nature wholly and the hierarchy of the society combined with the medieval and old mythology to be the materials of his play. He uses the existence of nature to be interrelated with the parts, the naturalistic phenomena and with human beings and their life problems. The whole universe or nature is the cosmic system in which human beings form the system of social structure and live in harmony with other system where every element in the cosmos has its meaning only in relation to the other parts (Swingewood, 1970: 61-62). Therefore, it attracted Shakespeare so much to 
interpret the image of the cosmic system and its parts that the content of nature is richly found in the play.

\section{B. THE CONTENT OF NATURE FOUND IN WILLIAM SHAKESPEARE'S KING LEAR}

\section{Cosmos}

In fact, the background of King Lear is the cosmos because men who become the actors and actresses in the play live in a concerned and interdependent universe. Cosmos is the nature and all spaces considered as a well-ordered system (Hornby, 1974: 193). The system, according to the structuralists, creates new concept that the world is made up of relationship of things; it claims that the nature of every elements in any given situation has no significance by itself, and in fact is determined by its relationship to all the other elements involved in that situation (Hawkes, 1977: 17-18). Lear asks the dear goddess nature to curse Goneril with sterility, because Goneril, a thankless child, has unnaturally disowned Lear. Lear's capital curse would scare the motherhood out of any woman except Goneril. However, Lear's appeal to nature is basically futile because the goddess nature is not violated. It is God, and not the goddess nature, who should be evoked in this damning curse. Lear would naturalize nature and unsex life because of Goneril's ingratitude and lack of love. Biological nature is not to blame, because the meaning of nature on itself depends on the intangible relation of love. Ingratitude, though unnatural in the sense of unkind, is not explained naturalistically or materialistically. Lear ironically seeks cause in nature. Lear says Goneril should have neither a babe to honor her nor a thankless child. Goneril has neither, but Lear has both a loving child and a loveless child. Lear's curse is superfluous. Goneril is already disnatured; all that is left is dry lust.

Both Lear and Edmund appeal to the goddess nature. Edmund the natural child, praises nature's lawless fertility and bids the gods stand up for bastards (Act I, Scene II). On the other hand, the father of an unnatural child bids nature to dry up in fruitless sterility. Nature can hardly answer both wishes. Both Lear and Edmund must learn that the gods that we adore are not gods in nature but gods 
above nature-love, wisdom, and justice. As a father who must protect and take care of his daughters, Lear forgot his true nature when he banished Cordelia. This also happens to Edmund. As a child, he should obey his father and be a friend with his brother, Edgar. Nevertheless, he does wrong deed because he makes a conspiracy with Gloucester to banish Edgar and with Cornwall and Regan to banish his own father, Gloucester. All things happening in the cosmos either it is because of the relationship among the parts of the microcosm, or among the parts of the macrocosm, and even among the parts of the microcosm and macrocosm have systemic meaning behind them. So the part of the cosmos which form the system of nature have its own meaning or represent things out of the reality resulted from the interrelationship among them. Cosmos or universe consists of microcosm and macrocosm which relate each other.

\section{a. Microcosm}

Microcosm (noun) is something, (especially man, by the ancient philosophers) considered as representing (on a small scale) mankind or the nature; it is miniature representation of a system existing in the universe (Hornby, 1974: 534). Microcosm or the small world of man, family, and civil affairs is directly linked to the great world or macrocosm of the universe (Main, 1962: 26). In broadest sense, however, microcosm includes all living things and unliving things on the earth which relate each other and they become the part of the nature.

\section{1) Man}

A man is a part of microcosm and as a man, Lear, the king of England who represents the proud one, is blind for the truth. A blind man should not swear by bright lights, but Lear ironically does. In the name of the sun, the moon (Hecate is both moon goddess and queen of black magic), and all the other orbs, Lear foully disclaims all his "paternal care" and banishes Cordelia (Act I, Scene I). Without realizing it, Lear creates darkness and anger on himself but he calls on the lights of heaven to witness his dark deed, not Cordelia's supposed crime. Lear is blinded by his golden illusion of self-righteousness; evil Hecate appears as a bright moon goddess (Main, 1962: 10). His pagan polytheism is equally deceptive. 
As a blind man, Lear also banishes Kent, his loyal servant, for speaking the truth of Lear's hideous rashness. Kent's love of Lear approaches Cordelia's; for, instead of pelting Lear with sweet phrase, he loves the king enough to tell him the truth on pain of suffering and banishment. In disowning a loving daughter and exiling a loyal servant, Lear turns sight into blindness, light into darkness, health into disease, and paradoxically, banishment into freedom (Craig, 1990: 984). Again, Lear ironically swears by Apollo, the god of light and medicine, whereas it is in vain to swear by Apollo if one foolishly closes his eyes to the light of truth or insanely kills his physician and bestows the fee upon the foul disease (Act I, Scene I). Diseased with folly and rashness, the sick, blind Lear swears by the god of medicine and light, but banishes the physician of love and the light of truth. "When majesty stoops to folly and willfully persists in that folly, then majesty dost evil" (Act I, Scene I). Lear's fanatical pagan piety is actually fantastic blasphemy. He swears by Apollo and Jupiter, but he does not believe in them. Lear is false to his own pagan god.

\section{2) Animals}

\section{a) Birds}

Shakespeare uses birds-sparrow, cuckoo and hawk-to represent the characters of Lear, Goneril and Regan. Sparrow represents the weak Lear and Cuckoo and hawk represent the ungrateful Goneril and Regan (main, 1962: 41). Having inherited half of their father's kingdom, Goneril and Regan immediately proceeds to disinherit their father. We do not realize the full horror of what is really happening here until the Fool says, "the hedge-sparrow fed the cuckoo so long, that it had its head bit off by its young" (Act I, Scene IV). Like the ungrateful young cuckoo, Goneril and Regan are bitting off Lear's head. They are like the hawk and figuratively eating their father, and doing the unnatural deed as naturally as they breathe. Unnatural cannibalism and symbolic crucifixion are both suggested in this ghastly image. The daughters who once said they loved their father "more than words can wield the matter" (Craig, 1990: 987) are now eating their father and their words. Goneril's and Regan's old mask of flattering love are now off, and we begin to see the true ugliness of their inhuman faces. 
Seeing this, the Fool says that Lear the king has been replaced by Lear the fool. To Goneril and Regan, Lear without his kingdom is harmless, a shadow. The old proud Lear is being transformed "from what he rightly is" (Act I, Scene IV) by the tyranny of his ruthless daughters. "This is not Lear, not Lear the proud king but Lear the suffering subject" (Act I, Scene IV). Order and hierarchy are reversed; the king has become the subject, and Goneril and Regan now sit at the head of the table.

\section{b) Fox, Ape and Ass}

A fox, an ape, or an ass, in this case, is the image given to the bad charactera character who just wants to get the fortune-of Edmund. It is allegory or the use of extended metaphor; everything being said on the literal level has an obvious meaning on another level (Reaske, 1966: 59). The major plot of Lear's family and the subplot of Gloucester's family merge in the figure of Edmund, who joins Cornwall, and of Gloucester, who must be disloyal to Lear if he becomes loyal to Cornwall and Regan. Except for the poor dupe Gloucester, the two wolves (Cornwall and Regan) and the fox (Edmund) join in the name of justice-to right the grievous wrongs done to them by Lear and by his vicious godson, Edgar. Edmund has bad personality and behavior and shows his consistency as a powerful character who always tries to size others. He has a great ambition to get his father's wealth and authority and likes to incite in order to gain what he wants.

Edmund's real curse is that he can be true to no one. He has already deceived himself and has been false to his goddess of nature; now he will lie to his father and to his brother. What makes Edmund's deception so skillful is that he lies with seeming good intentions, in the name of brotherly love. In destroying his brother, Edmund appears to be trying to save him. Edmund is a liar and an ape. He apes his father and lies to his brother. He deceives his father by showing a forged letter telling that Edgar makes a conspiracy to kill Gloucester and to rebel against Cornwall. He says that it is Edgar who writes the letter and he finds it in the toilet. "It is his hand, my lord; but I hope his heart is not in the content" (Act I, Scene II). Ironically, Gloucester believes in Edmund's lies and he desperately needs spectacles to see through Edmund's forged letter. Gloucester is angry with Edgar; 
he is blind in both eyes, to Edmund's treachery and to Edgar's honesty. Edmund has successfully poisoned the mind of his credulous father and aroused the fears of his noble brother. The diabolical Edmund may scorn Edgar's foolish honesty; but in the long run, as the proverb goes, "The devil is an ass." Edmund is a liar and an ape and an ass (Main, 1962: 29).

Since Edmund always frightens Edgar, he then escapes from the castle and goes to the heath. Believing in Edmund's lie, Gloucester impulsively disinherits and disclaims Edgar by giving Edmund his land and authority and giving Edgar Edmund's bastardy. Now Edmund has the lands and authority he originally wanted. Edmund, after fulfilling what he has wanted, becomes an ungrateful man. His unpatriotic motive is self-interest and ambition and they become the basic of banishing his father. When Gloucester helps Lear in the heath, he informs Cornwall of his father's bad deeds and accuses him as a betrayer. For his false, Cornwall in conspiracy with Edmund, then punishes Gloucester by stabbing his eyes, so he has been blind ever since. Edmund also becomes the commander-inchief of the armies of Goneril and Regan to face the army of Cordelia from France. He is also in love with Goneril. It is the best evidence that the world of Goneril and Edmund is symbolically hell is that there moral values are "turn'd the wrong side out" (Act IV. Scene II) for hell is the place where evil is good, and Satan is God. To the evil, good is evil and evil is good (Main, 1962: 142). To the infernally feminine Goneril, the honest, moral Albany is a mild, cowardly fool, and the cool, treacherous Edmund is the ideal of virtuous manhood. "O, the difference of man and man!" (Act IV, Scene II) says Goneril, unable to tell which man is angel and which devil.

Accidentally, Regan also falls in love with Edmund. Edmund now is the pure Machiavellian opportunist who sacrifices everyone to his inflated ambition (Main, 1962: 186). He betrays those-Goneril and Regan-who love him and he is treacherous to the innocent-Albany and Cordelia. Goneril and Regan, aptly alluded to by snake imagery, betray their husbands and each other for Edmund's love; perhaps it is poetic justice that he betrays them. With instincts of a gigolo, Edmund is supremely pragmatic in his love for the wicked sisters. When he is not 
with the woman he loves (actually, he loves only himself); he pragmatically loves the woman he is with. All Edmund cares about is marrying the survivor, for either Goneril or Regan could be queen and thereby make Edmund king. Ready to burn any bridge behind him, Edmund survives on the unethical policy of instant expediency (Main, 1962: 187). He in fact knows right from wrong, but he uses this knowledge selfishly, not morally. His whole mind and moral sense are made subservient to his self-interest. Reason and morality are servants of the will, not master of it. Of the bad deeds Edmund did, only sentimentalists would excuse him, a "most toad-spotted traitor" (Act V, Scene III), for his unconscionable treachery. He is false to his gods, brother, father, and to Albany. To be false to one is to be false to all (Main, 1962: 198).

\section{c) Wolves}

Cordelia calls the bad characters of Goneril and Regan as wolves. The metaphoric way of calling by comparing of the two unlike things (Reaske, 1966: 59 ) is extremely effective and forcefull. Wolve represents the bad character who is ready to tear up all things. When she departs, she knows that her sisters are wolves and that unfolding time shall unmask them. King Lear, ironically, has banished Cordelia to safety in France while he stays in England with the wolves, Goneril and Regan. Seeing how rashly Lear has treated his beloved Cordelia and the loyal Kent, the two evil sisters immediately plot a conspiracy to rid themselves of their infirm and choleric father. The outrageouss thing about their planned cruelty is that it is completely rational but viciously motivated. Were Lear a dilapidated old house tottering on shaky foundations, their cold logic of destruction would be justified. But this old house is a human being, not to mention a father who had just given Goneril and Regan all of his kingdom. Inhumanity is the inevitable consequence of heartless reason. Cordelia's loving heart is much rarer than her sisters' sophisticated minds. Without character, all knowledge, reason, and logic are deadly. They really want to destruct their father in their own way.

\section{d) Bull}

The word bull is only a metaphor when one says that one thing is something else (Reaske, 1966: 59), and it is quite match for the call of Kent, Lear's loyal 
servant. Kent always comes to forwards to defend Lear from Goneril's and Regan's servants especially Oswald. He always wins both in words and in blows when he fights with Oswald. Though Kent wins over Oswald in the immediate din and gobble, he later loses to Cornwall. Despite his disguise, Kent is no subtle foe. Rather he is a bull when he sees rose-colored Oswald (Main, 1962: 59). Both in language and action Kent is salty and blunt, full of vigor, steam, and sass. Whether to a king or servant, Kent is unafraid to tell a man to his teeth what he thinks of him. Though overly aggressive, Kent is on the side of right and justice, a position that practically assures his confinement in the stocks, since thus far it is a world where might is right. Oswald could not be a greater contrast. Afraid to fight, this coward is, according to Kent, a vain sycophant who serves more as a bawd and pander than as a servant. The significant description for Oswald, aside from Kent's commonplace curses, are "lily-livered...glass-gazing, superserviceable, finical rogue (Act II, Scene II). Certainly, Oswald is vanity and plays a puppet's part. Both Kent and Oswald are servants. However, the sinewy Kent serves from conviction and strength; the foppish Oswald serves from weakness and selfinterest. Unlike Kent, Oswald would never return in disguise to serve Goneril if she had banished him. Kent will suffer far more than would Oswald to serve his master.

\section{3) Fiend and Sea Monster}

A Fiend represents the bad character of daughters who always treat their father badly. While, monster, in this case, is not the real monster but it is only the symbol of bad characters of Goneril and Regan who have destroyed their own father. Having been driven away by Goneril, Lear goes to Regan to stay in her palace. But Regan has made a conspiracy with Goneril to give a bad learn to Lear, their common enemy. They refuse Lear to stay in Regan's palace. Lear then goes somewhere aimlessly in the heath. Prophetically and helplessly, King Lear cries out, "O, let me not be mad, not mad, sweet heaven. Keep me in temper: I would not be mad" (Act I, Scene V). In his semi-soliloquy with his Fool, Lear reveals the mental vise that will squeeze him to the breaking point of madness. The double forces preying on Lear's mind that will cause his inner breakdown are his own 
unkindness to the loyal Cordelia, and the monster ingratitude Goneril and Regan's unkindness to him. Experiencing this, no longer does Lear appeal to his favorite goddess, nature, but rather to Sweet heaven. Nature serves for cursing, but heaven is required for praying (Main, 1962: 49). Too late does Lear fear he will forget his nature. Lear forgot his true nature when he banished Cordelia. Now he must smell out the festering stench that he has long neglected to spy into (Act I, Scene V).

The ambivalent strategy of loss and gain resulted from the bad treatment of Goneril and Regan to Lear begins: As Lear materially falls, he spiritually gains. He loses power but gains insight (Main, 1962: 43). Lear begins to see. First, he sees the difference between Goneril, Regan and Cordelia. His material investment in Goneril's and Regan's love has brought ingratitude of "a marble-hearted" daughters (Act I, Scene IV). On the other hand, Cordelia's earlier blunt honesty in saying "Nothing" now appears as a "most small fault," although it had formerly appeared ugly. Unnatural ingratitude between child and parent is expressed in bestial and satanic imagery. Goneril and Regan are called "fiends, and sea monsters" and "detested kites" (Act I, Scene IV). They are fiends because they have given bad punishment in form of bad treatment to their father. They are like monsters who have eaten and destroyed their own farther. Ingratitude dehumanizes and subhumanizes. Second, Lear sees his own blindness that "let thy folly in, and thy dear judgement out" (Act I, Scene IV). Although Lear blames Cordelia's original "small fault" for wrenching his "frame of nature," thus changing his love to gall, it was his own, selfish pride that was the cause. Lear can see Goneril's vice better than Cordelia's and Regan's virtures. Actually, the only "engine" that can wrench Lear's "frame of nature" is lovelessness. In fact, the frame of all nature and the universe, as the play demonstrates, rests on the only 'fix' $d$ place' there is-the even-balanced, jeweled bearing of Cordelia's love (Act I, Scene IV).

In fact, monster, the unnatural monster, is also the symbol of Lear's bad treatment to Cordelia. A symbol is something that means more than what it actually is (Jones, 1968: 56). Disinheriting his daughter in a storm of violent will, Lear banishes Cordelia “without our grace, our love, our benison” (Act I, Scene I). 
Lear has just disinherited himself; for it is he, not Cordelia, who is without grace, love, and blessing and who can never again endure himself without them. It is too late does Lear fear he will forget his nature. Lear forgot his true nature when he banished Cordelia. Now he must smell out the festering stench that he has long neglected to spy into (Act I, Scene V). Eventually, Lear will change, not by Kent's rational appeals but by the great teaching emotions of fire and forgiveness, ingratitude and tenderness. The third degree burns of disillusionment will come from Goneril and Regan, followed by the healing salve of Cordelia. Only then will Lear see that Cordelia's little seeming substance is transparent spirit itself.

\section{4) Stock}

Before Lear goes to Regan's palace, he asks Kent to go first bringing a letter informing that Lear intends to stay in her palace. However, on arriving in Regan's palace, Kent finds Oswald, Goneril's servant, bringing a letter from Goneril informing that their father will go and stay in Regan's palace and asks her to refuse him. Knowing this, Kent attacks Oswald and the noisy duel happens. In the end, Regan and Cornwall come out of the palace to stop the duel. They then put Kent in the stock. When Lear arrives there and knows the condition of Kent who is put in the stock, he is very angry with Regan and Cornwall. He continues to find the one who puts Kent in the stock "who stock'd my servant? Regan, I have good hope thou didst not know on ' $t$ " (Act II, Scene IV). The stock represents the defeat of Lear by his daughter, Regan and Cornwall. They put Kent in the stock because they want to mock and curse Lear.

Kent, like human bait set out by the head-hunters Cornwall and Regan, is found by Lear and the fool. In outrage, Lear swallows the bait, as it were, reacting with a sense of strangulation and smothering. The effect of this emotional epigastric attack is a choking in the throat. Lear orders this climbing sorrow down, largely to no avail. Symbolically, if Kent is being tied by the legs, Lear is tied by the neck, like bears and dogs (Main, 1962: 69). The effrontery and deliberate insult of his personal servant in stocks lands a direct hit on Lear's pride. Knowing this, Lear reacts it in great anger. Unlike Lear, the fool provides a satirical, ethical reaction. He immediately evaluates the truth of the situation and of Lear's world. 
It is eminently a world where truth is put in the stocks; the same world, in fact, where "truth's a dog must to kennel" (Act I, Scene IV). It is a world where animals and men are treated essentially alike- as slaves. It is a world where wealth, power, and might rule and corrupt; a world that disregards poverty. It is a thoroughly naturalistic world of behavior; a venal world of selfish gain, even between father and children and a world where kindness is bought (Main, 1962: 70). Kent in the stocks is a burning insult, a lesson in worldly ethics, and a sure symbol of truth and freedom as found in this world.

\section{5) Castle, Heath, and Hovel}

King Lear experiences one of his great moments of enlargement, a moment in which Lear widens his spiritual horizon and assumes the responsibilities for common humanity. Only now does Lear's suffering become an instance of all suffering. Now his pain is made one with the world's pain. Lear's growing spirit and widened sense may be traced in geographical symbolism. Lear's progress has been from castle to heath, and presently, to hovel. These three abodes represent three major attitudes attending in Lear's heart. In the castle, Lear was proud, blindly proud and willful until Kent told King Lear to "see better" (Act I, Scene I). On the heath have come the "heart-struck injuries"(Act III, Scene I) of pain and suffering when Lear feels Goneril and Regan's filial ingratitude and cruelty. On the heath or outdoors itself becomes symbolic, a revelation of the truth of man's humanity. Outdoors, Lear discovers what a wretch man is without a house. The heavens are more just if man has a house, because houseless man is no more than a beast (Main, 1962: 101). By becoming almost an animal, Lear learns that man is more than an animal, and sees how much of what he sees on which he firstly never saw at all. The third attitude contending in Lear's heart is humility, represented by the low hovel that requires stooping when one enters in it. No longer is the proud King Lear the first to enter. He bids Kent and the fool to go first. From castle to heath to hovel, therefore, King Lear experiences a new spiritual dimension, humility; and he discovers a new moral magnitude, and justice. In the castle, Lear is, symbolically, neither God nor justice; in the hovel he is becoming both. 


\section{6) Clothes}

Despite his personal suffering, Gloucester is acutely aware of the suffering of others. He asks the Fool and Kent to "bring some covering for this naked soulEdgar" (Act IV, Scene I). Gloucester drove Edgar to nakedness; now he will unknowingly clothe his disinherited son. Clothing, in this case, is a symbol of charity (Main, 1962: 138). In their misery, Edgar and Gloucester comfort each other. Ironically, however, Gloucester identifies the spiritually rich Edgar, disguised as Tom, as a beggar man. It is Gloucester who is the beggar man, and only eternal ancient love can help such blind beggar. Gloucester also considers that Tom is the insane. Realizing he will be led by poor Tom, Gloucester says, "tis the times' plague, when madman leads the blind" (Act IV, Scene I). A triple meaning is implicit here. The literal meaning states that poor mad Tom will lead the poor blind Gloucester. However, the ironic reality is that sane Edgar is leading Gloucester who is symbolically no longer blind; the disguised leads the disillusioned. The time's plague consists of active evil and blind folly, moral diseases that have infected the whole kingdom (Main, 1962: 138).

\section{7) Music and Medicine}

The imagery of music and medicine prepares us for the awakening and recovery of King Lear. First, the stage directions call for 'soft music playing,' later to become louder to awaken the king. When the sphere of the universe were in order, then it was believed that music was heard. Thus, music, the symbol of harmony and peace, anticipates a return to health and sanity, to love and reunion. "The untuned and jarring sense" (Act IV, Scene VII) of Lear will be wound up and restored to harmony. No such music has been heard earlier in the play; only war drums and cacophonous storms. A second image, perhaps the most important, is medicine. Here physical medicine represents spiritual healing, and Cordelia herself is the medicine. Cordelia says, "Restoration hang/Thy medicine on my lips; and let this kiss/Repair those violent harms that my two sisters/Have in thy reverence made!" (Act IV, Scene VII). The only place restoration can hang its medicine is on Cordelia's lips, the same lips that originally told Lear the truth "Nothing, my lord," and now will restore Lear to sanity with a kiss of love. 


\section{8) Wheel}

The wheel, in this regard, represents the up and down of chronicle of life (Jones, 1968: 54). For Edgar and Edmund, the wheel has come full circle. The final relationship of these brothers is purely melodramatic. The good Edgar, long on the bottom of the wheel of fortune, is at last on top; and the evil Edmund, long in the ascendancy, ends up at the bottom. Formerly, Edmund becomes an honorable man; he gets high position, has lived in the castle and to be a rich man for a long time but Edgar becomes no one, a beggar, has lived in the hovel, and has nothing. But now' Edgar can defeat Edmund. Clearly, the wheel of fortune is also suggested as the wheel of Nemesis or of justice. In the final arbitrament good wins and evil loses; righteousness punishes unrighteousness. The medieval formality of this final contest includes the challenge by a herald and a duel by rule of knighthood (Main, 1962: 198). This medieval ritual emphasizes the scrupulous justice of Edgar's cause, so that his capital punishment for capital treason cannot be branded as a wild revenge. Only sentimentalists would excuse Edmund for his unconscionable treachery. Edmund's bastardy explains his motives but does not excuse his deeds. He is false to his gods, brother, father, and to Albany. To be false to one is to be false to all. Yet perhaps Edmund's gods are false to him, for they do not, as he once maintained, "stand up for bastards!" (Act V, Scene III).

\section{b. Macrocosm}

Macrocosm is the universe, nature and any great world which covers all things out of microcosm (Hornby, 1974: 509). It is the part of nature out of microcosm which also influences the existence microcosm and becomes the background of the play.

\section{1) Sun, Moon and Other Orbs}

The sun, the moon and the other orbs, in this case, mean more than what they actually are. The sun is a symbol of bright life; the moon is the symbol of peaceful life created by Hecate in Greek Mythology and; other orbs represent the beautiful world; they in broadest sense represent the light of heaven (Jones, 1968: 70). A blind man should not swear by bright lights, but Lear ironically does. In the name of the sun, the moon and all the other orbs, Lear foully disclaims all his 
paternal care and banishes Cordelia. Without realizing it, he calls on the lights of heaven to witness his dark deed, not Cordelia's supposed crime. The sun, the moon, and other orbs may control our existence; but despite such fatalism, they, in turn, are controlled by the power of love. As the rest of the play proves, Lear's treatment of Cordelia determines the heavens' treatment of Lear. Not "the sacred radiance of the sun," (Act I, Scene I) but the sacred love of Cordelia is the controlling power in the play. The banishment of Cordelia is an invitation to cosmic chaos (Main, 1962: 11). Even Lear does not believe that Cordelia does not love him. Therefore, by his pagan polytheism- Apollo, the god of light, and Jupiter, the god of medicine (Main, 1962: 10), he swears to banish Cordelia although he does not believe in them. The sun, the moon, and the other orbs naturally control and honor the existence of human beings. Their bright lights are spiritually the symbol of the lights of heaven. The lights of heaven are reflected through the light of true love from Cordelia to her father, Lear and from Edgar to Gloucester.

\section{2) Storm, Rain, Thunder and lightning}

Storm, rain, thunder and lightning are four things which often come in the same time. If they are interpreted as naturalistic phenomenon, they mean very little. They are purely a weather report such as wind currents, high and low pressures, and heavy cloud condensation. However, psychological, symbolic, and parodistic interpretations yield much richer meanings. Psychologically, the storm is Lear's spirit storming, a massive emotional relief in which Lear cries out in literate outrage (Main, 1962: 91). If Goneril and Regan have cut Lear's throat, Lear now would cut the throat of the world. Lear hopes that the storm would destroy the world as the reprisals for his daughters' heartless cruelty. Symbolically, the storm expresses a double judgment and a double world. Judgmentally, the tempest expresses a judgment on Lear as much as it does Lear's judgment on the world. The raging storm followed by the rain may be interpreted as a parody of Noah's flood, namely, a divine judgment on mankind. The point of parody is the contrast between Yahweh and Lear. Biblically, Yahweh or God willed the flood to destroy mankind but preserve a remnant, the seeds of a new 
mankind (Main, 1962: 92). But because of his anger after being banished by Goneril and Regan, Lear by the storm and rain expects that they would destroy all human beings and even including himself. The sign of rainbow symbolizes God's covenant with Noah to show mercy on mankind. Thus, beyond God's judgment was His mercy. As a parody, Lear's deluge retains the judgmental destruction but omits the remnant and rainbow of recreated life. Lear evokes the heavens to destroy all life: "Smite flat the thick rotundity o' the world/crack nature's moulds, all germens spill at once/that make ungrateful man" (Act III, Scene II). Here no seeds (germens) are to be saved, and the pregnant world (thick rotundy) is to have a cosmic abortion. Because of his great anger to his daughters, Goneril and Regan, it is seen that Lear asks the storm to wipe out all life by which he does not realize that he will also die for it.

Meanwhile, thunder and lightning rebuke Lear's follies as much as he rebukes Goneril and Regan's evils. It Looks that Lear is suffering inhuman cruelty; yet it also seems that he is no innocent victim. Lear's folly in selling love is being punished. If our sense of justice is against Lear, our sense of pity is for Lear and against justice (Main, 1962: 91). Thus, the storm, thunder and lightning are only naturalistic phenomena but the three elements may be interpreted as the rage of nature over the bad deeds of children towards their parents. They are also the direct reward over the unjust action of a father, Lear, to the real obedient daughter, Cordelia.

\section{3) Earth, Air, Fire and Water}

The storm mentioned above represents the great anger of Lear to his daughters which cause the disharmony of nature and a chaos of the fretful elements. The elements of nature presented by Greek materialistic philosopher, Empedocles, consisting of the earth, air, fire and water (Main, 1962: 88) are in radical disharmony; each attacking the other "the to-and-fro-conflicting wind and rain" (Act III, Scene I) because of the causal false. The earth as a home of human being is destroyed by the storm and rain "the wind (would) blow the earth into the sea,/ Or swell the curled water "bove the main,/that things might change or cease" (Act III, Scene I) amidst Lear's anger because he was driven away by his 
daughters, Regan and Goneril. Fire symbolizes Lear's anger. In his anger, he mocks them "....rumble thy bellyful! Spit, fire! Spout, rain! Nor rain, wind, thunder, fire, are my daughters: I tax not you, you elements, with unkindness; I never gave you kingdom, call'd you children,...” (Act III, Scene II). God punishes Lear who has sold love and banished Cordelia from England by sending big storms and big rain to destroy earth as a symbol of life.

One of the most dominant in the event is the water as it is stated in "Swell the curled waters bove the main" (Act III, Scene I). According to Classical Greek mythology, water symbolizes passion because Venus was born from the sea. But, in this case, passion is great anger "the passion of eyeless rage" Lear possesses which is overwhelming himself. However, in Christianity symbol, water suggests purification (baptisme) which means to purify Lear's sin and bad deeds he has done (Main, 1962: 89). Lear was tempted to the flatter of Regan and Goneril which Greek classical mythology call them wild centaur or half human and half animal creature. He forgot Cordelia, his obedient daughter called kind Chiron or goddess who took care the god Archilles (Main, 1962: 90). In addition, the air represents freedom from oppressive situation. Driven away from his own kingdom, Lear underwent physical and psychological miseries in his old age until he found "sweet marjoram", an old medicine to cure brain ill. The old medicine was no one else but Cordelia, his beloved daughter whom he banished and now she came to help him. Having met Cordelia, Lear feels happy because he gets freedom from the cruel daughters, Goneril and Regan and finds new air to build bright life in his old age.

In fact, for Empedocles, the central symbolic image here is destruction by contending force of nature (Main, 1962: 88). For him, "matter" consists of the four elements, and "energy" of the two forces of love or strife. When love rules, the four elements are fused in a perfect sphere; harmony rules. But when the strife rules, the elements are separated and division rules. The state of the world depends on which power is ruling, love or strife. The cause of the cosmic conflict would be strife engaged in banishing love. The cause is that Lear is engaged in banishing Cordelia and Goneril and Regan are engaged in banishing Lear. Thus, 
the four elements-earth, air, fire and water-are the elements which may be unified in harmony if there is love but they are separated if there is strife. The earth is the place where human beings live on; air represents the situation of freedom of life; fire represents the anger and; water symbolizes purification. Those four naturalistic elements in harmony represent the life and its problems.

\section{4) The Insane}

After being banished by his daughters Goneril and Regan in the heath in the storm and rain, longer and longer Lear becomes frustrated and insane. The insanity of Lear is the symbol of judgment when he banishes Cordelia. Lear's loss of sanity is now an inescapable punishment for his earlier loss of reason. Had Lear properly used his reason in recognizing Cordelia's love, he would not now have lost his reason in suffering Goneril and Regan's cruel ingratitude. The punishment of madness is the cost of the abuse of reason. Because the storm and rain in the heath become bigger and bigger, he then gets in the hovel and meets Edgar who disguises himself as a beggar and changes his name as Tom. Because of his unusual clothes and attitude, Lear thinks that Tom is also the insane. Lear's increasing insanity is betrayed in his attitude toward the madman, poor Tom. In Lear's eyes, madness has now become wisdom. He has transformed a madman into a philosopher, a "learned Theban, and a good Athenian" (Main, 1962: 111). In fact, these titles will be mockery to everyone but not for Lear, who seems to find his closest bond with the insane Tom rather than the sane Kent. Thus Gloucester also considers that Tom is the insane. Realizing he will be led by poor Tom, Gloucester says, "tis the times' plague, when madman leads the blind" (Act IV, Scene I). A triple meaning is implicit here. The literal meaning states that poor mad Tom will lead the poor blind Gloucester. However, the ironic reality is that sane Edgar is leading Gloucester who is symbolically no longer blind; the disguised leads the disillusioned. The time's plague consists of active evil and blind folly, moral diseases that have infected the whole kingdom (Main, 1962: 138). 


\section{5) Death}

All human beings will die and death is natural tragedy. In this play we see that all the characters die in different causes. After knowing the cruel deeds done by Cornrwall, Regan, and Goneril who have banished Lear and stabbed Gloucester's eyes, the courageous servant dares to oppose them. He not only rebels against his master but also kills Cornwall. The servant is outraged at cornwall's gouging out Gloucester's eyes. Cornwall miscalculates the effect his horrid act will have upon his loyal but humane servant. Absolute cruelty generates its own Nemesis (Main, 1962: 128). Despite his allegiance to his master, the servant feels a higher allegiance to his own conscience, an innate sense of right and wrong. He respects moral authority but not the political authoritarianism of a bad master. Man's moral duty, as exemplified in the heroic servant, is to act as one thinks best. In return of his bravery to kill Cornwall, Regan stabs the servant in the back. The servant dies; he does not save Gloucester from blindness, but he destroys Cornwall "in the chance of anger"(Act III, Scene VII) which is also a lucky chance for Edmund to replace Cornwall, both as duke and husband. Courageous moral integrity is tragic; it costs Gloucester his eyes and the brave servant his life, both suffering servants indeed. Truth, right, and justice are all bloody. The world does not want truth; so it ties it to a stake (Act III, Scene VII), nails it to a cross, or a cross disguised as a chair, and tortures and destroys it. Such tragic facts of truth are banned by all sentimentalists (Main, 1962: 129).

In certain time, Edgar as poor Tom emerges as the militant hero. He saves his father a second time, from being murdered instead of from suicide. Using a peasant accent and a heavy cudgel, he kills the serviceable villain Oswald, Goneril's servant and discovers the treacherous plot of the murderous lechers, Goneril and Edmund. Meanwhile, Gloucester dies of the sick after the long misery and torture, almost literally, of a broken heart. "His flaw'd heart ... twixt two extremes passion, joy and grief, burst smilingly" (Act V, Scene III). But before he dies, Edgar tells him that he is his real son, Edgar, whom he has ever banished, and he promises to kill Edmund for the reward of his bad deed. The joy is over the discovery of Edgar, and the grief is over the suffering of Edgar, suffering inflicted 
by Gloucester himself. More significantly Gloucester's grief is his squirming selfknowledge, and his joy is his calm self-acceptance. Through Edmund's treachery comes the self-knowledge, and through Edgar's love comes the self-acceptance (Main, 1962: 200). Gloucester also commits a sin because he has made conspiracy with Edmund to banish Edgar, the good son and becomes angry to Edmund because Edmund has betrayed him and destroyed his family.

Similarly, the dirty lives and the decayed souls of the sisters Goneril and Regan finally come to a violent, self-destructive end (Main, 1962: 202-203). They, who have been so false to their own father, cannot be expected to be more faithful to their husbands. They soon grow tired of showing even appearance of love and duty, and plainly let it be seen that they have given their love to another man. Each of them falls in love with the same man, Edmund. After the death of her husband, Cornwall, Regan at once declares her intention to marry Edmund. This makes Goneril angry and excites her jealousy. Because of her jealous passion for Edmund, Goneril poisons Regan. But her husband, the duke of Albany, discovers her deed and puts her in the prison where she soon commits suicide, out of empty frustration. Both Goneril and Regan die for nothing. The chemistry of evil is that it destroys itself. Death is the only escape hatch from the prison of unfeeling. These demonic sisters gain nothing in their losses, as do Gloucester and Lear (Main, 1962: 203). These wicked sisters are hardly sisters; they acknowledge neither their father nor each other. They are merely "unnatural hags" (Act II, Scene IV) whose "plaited cunning" (Act I, Scene I) ultimately destroys themselves instead of their father. The imagery of death here is the judgment of God for the bad deeds of the two wicked sisters who have destroyed their father, sister and for their betrayal of their respective husbands.

Cordelia also finds bad fortune. The armies which Goneril and Regan have sent out under the command of Edmund, the bad earl of Gloucester, are successful to defeat her army. Cordelia is then taken to prison but soon afterwards Edmund hangs her. She dies and her death is held in the higher extremity of love (Main, 1962: 206). Knowing Cordelia's death, Lear roars “and my poor fool is hanged/howl, howl, howl, howl/Cordelia is dead, dead as earth.../she is gone for 
ever... (Act V, Scene III). After the death of Cordelia, Lear becomes frustrated. Owing to his despair, old age and his misery, Lear does not live long after his kind child's death. Before the king dies, the good earl of Kent tries to tell him that it is he who has followed him under the name of Caius. Lear's troubled brain cannot understand how that can be, or how Kent and Caius can be the same person, so Kent thinks it unnecessary to try to explain. This faithful servant to the king, old and full of grief, dies soon after his master. Then, the bad earl of Edmund is killed in a single fight with his brother, Edgar who has planned to take revenge for his betrayal to his father. So all the characters in the play die, and the story ends with them.

\section{6) Hell and Heaven}

Hell and Heaven, in this regard, represent the judgment of God given to the human beings. Hell symbolizes the justice which punishes the guilty (Main, 1962: 118). Although Lear is putting Goneril and Regan on trial for their sins against him, he himself is on trial and under punishment for his sin against Cordelia. Lear is being punished for his sins by the sins of others; how he treated Cordelia is repaid by the treatment of Goneril and Regan. The entire ordeal of Lear's suffering is a man enduring the tortures of hell. Kent, who faithfully witnesses Lear's sufferings, will speak of Lear existing "upon the rack of this tough world" (Act III, Scene VI). The wheel and the rack are classic torture instruments of hell. If the literal setting of the present scene is a farmhouse and the surrealistic setting is a courthouse, the symbolic setting is hell itself (Main, 1962: 118). Lear, therefore, is symbolically in hell where justice punishes the guilty and hell will hold Lear's soul as hostage until Cordelia returns to redeem all the wrath and all the weeping.

Hell also suggests the love relationship between Goneril and Edmund. The world of Goneril and Edmund is symbolically hell is that there moral values are "turn'd the wrong side out" (Act IV, Scene II). For hell is the place where evil is good, and Satan is God. To the evil, good is evil and evil is good. To the infernally feminine Goneril, the honest, moral Albany is a mild, cowardly fool, and the cool, treacherous Edmund is the ideal of virtuous manhood. "O, the 
difference of man and man!" says Goneril, unable to tell which man is angel and which devil (Act IV, Scene II).

Meanwhile, Heaven represents the happy and peaceful life Gloucester hopes to be given to Edgar. During in the heath under the good treatment of Poor Tom, Gloucester soon realizes that Edmund has betrayed him. He fulfills the sacrament of penance like contrition, confession and satisfaction (Main, 1962: 139). His contrition begins the moment he recognizes his follies. So intense is his sorrow and self-reproach that he has changed paths; his way now is to Dover, not back to his castle where he committed his follies. While his confession has already been made to Lear and unknowingly to Edgar; he confesses his sins to Edgar and admits his blindness, although in the third person. He is satisfied to accept the penalties for the sins. He asks the Heavens to make Edgar happier by making himself more wretched. It looks that Gloucester is quite satisfied with what he experiences, so he expects the Heavens which represent the happy and peaceful life given to Edgar. The major shift in spiritual direction for Gloucester will be from Edmund's cruelty to Edgar's charity, from ingratitude for kindness to gratitude for forgiveness. Gloucester can judge himself, but the gift of forgiveness must come from Edgar, Gloucester's sole comfort and compass.

The word "Heaven" is also used to express Cordelia's true love to her father, King Lear. The imagery used here to describe Cordelia establishes her functional role as a forgiving angel. Her tears and eyes are divinely described as "the holy water from her heavenly eyes" (Act IV, Scene III). This is genuine holy water, the kind used for baptism and consecration, not the hypocritical "court holy water" found in Goneril and Regan's dry castle (Main, 1962: 149). Water becomes the major symbol of purification and regeneration. In Cordelia's tears Lear will find forgiveness and redemption. Cordelia's chief qualification for angelic divinity is her absolute lack of any hate, revenge, or vindictiveness toward her father who has banished her and given her nothing.

In addition, the imagery of hell and heaven is that after reemerging from 'the grave,' Lear pictures himself as having been in hell on 'a wheel of fire' and Cordelia as 'a soul in bliss' from paradise. The symbolic transition here is from 
hell to heaven, from division to reunion. Although it is "a purging as much as a punishing 'wheel of fire,' the greatest punishment is Lear's 'own tears' that 'scald like molten lead" (Act IV, Scene VII). To extend the suggested metaphor of alchemy, Lear's lead tears will be transformed into golden tears by the 'holy water from Cordelia's heavenly eyes' (Main, 1962: 179).

\section{CONCLUSION}

The Content of Nature Found in William Shakespeare's King Lear varies. Cosmos becomes the main background of the play because men who become the actors and actresses in the play live in a concerned and interdependent universe. Cosmos is the nature and all spaces considered as a well-ordered system. The system, according to the structuralists, creates new concept that the world is made up of relationship of things; it claims that the nature of every elements in any given situation has no significance by itself, and in fact is determined by its relationship to all the other elements involved in that situation. Cosmos, in broadest sense, consists of microcosm and macrocosm.

Microcosm includes man, animals (birds, fox, ape, ass, wolves and bull), fiend and sea monster, stock, castle, heath and hovel, clothes, music and medicine, and wheel. The first is a man. A man is a part of microcosm and, in this case, it is represented by the character of Lear. As a man, Lear, the king of England who represents the proud one, is blind for the truth. He divides his kingdom based on love expression of his daughters for which he gives half of his kingdom to Goneril and a half to Regan but gives nothing to Cordelia and even banishes her. Lear also banishes Kent, his loyal servant, for speaking the truth of Lear's hideous rashness. The second is animals. They are birds, fox, ape, ass, wolves, and bull. Shakespeare uses birds-sparrow, cuckoo and hawk-to represent the characters of Lear, Goneril and Regan. Sparrow represents the weak Lear and Cuckoo and hawk represent the ungrateful Goneril and Regan. Having inherited half of their father's kingdom, Goneril and Regan immediately proceeds to disinherit their father. Like the ungrateful young cuckoo, Goneril and Regan are bitting off Lear's 
head. They are like the hawk and figuratively eating their father, and doing the unnatural deed as naturally as they breathe.

Besides using the birds, Shakespeare also uses fox, ape and ass. A fox, an ape, or an ass, in this case, is the image given to the bad character-a character who just wants to get the fortune-of Edmund. It is allegory or the use of extended metaphor; everything being said on the literal level has an obvious meaning on another level. The major plot of Lear's family and the subplot of Gloucester's family merge in the figure of Edmund, who joins Cornwall, and of Gloucester, who must be disloyal to Lear if he becomes loyal to Cornwall and Regan. Except for the poor dupe Gloucester, the two wolves (Cornwall and Regan) and the fox (Edmund) join in the name of justice-to right the grievous wrongs done to them by Lear and by his vicious godson, Edgar. In destroying his brother, Edmund appears to be trying to save him. Edmund is a liar and an ape. He apes his father and lies to his brother. Ironically, Gloucester believes in Edmund's lies and he desperately needs spectacles to see through Edmund's forged letter. Gloucester is angry with Edgar; he is blind in both eyes, to Edmund's treachery and to Edgar's honesty. Edmund has successfully poisoned the mind of his credulous father and aroused the fears of his noble brother. Edmund, the devil is an ass. Edmund is a liar and an ape and an ass.

Wolves are the words Cordelia calls for the bad characters of Goneril and Regan. A wolve represents the bad character who is ready to tear up all things. When Cordelia departs, she knows that her sisters are wolves and that unfolding time shall unmask them. King Lear, ironically, has banished Cordelia to safety in France while he stays in England with the wolves, Goneril and Regan. Another animal used by Shakespeare to express the character of a man is the bull. The word bull is only a metaphor and it is quite match for the call of Kent, Lear's loyal servant. Kent always comes to forwards to defend Lear from Goneril's and Regan's servants especially Oswald. He always wins both in words and in blows when he fights with Oswald.

The third is fiend and sea monster. A Fiend represents the bad character of daughters who always treat their father badly. Similarly, monster, in this case, is 
the symbol of bad characters of Goneril and Regan who have destroyed their own father. Having been driven away by Goneril, Lear goes to Regan to stay in her palace. But Regan has made a conspiracy with Goneril to give a bad learn to Lear, their common enemy. They refuse Lear to stay in Regan's palace. Lear then goes somewhere aimlessly in the heath. For this, Goneril and Regan are called "fiends, and sea monsters" and "detested kites". They are fiends because they have given bad punishment in form of bad treatment and banishing their father. They are like monsters who have eaten and destroyed their own farther. In fact, monster, the unnatural monster, is also the symbol of Lear's bad treatment to Cordelia. Disinheriting his daughter in a storm of violent will, Lear banishes Cordelia without any grace, love, benison.

The fourth is stock. Before Lear goes to Regan's palace, he asks Kent to go first bringing a letter informing that Lear intends to stay in her palace. However, on arriving in Regan's palace, Kent finds Oswald, Goneril's servant, bringing a letter from Goneril informing that their father will go and stay in Regan's palace and asks her to refuse him. Knowing this, Kent attacks Oswald and the noise duel happens. In return, Regan and Cornwall put Kent in the stock. The stock represents the defeat of Lear by his daughter, Regan and Cornwall. They put Kent in the stock because they want to mock and curse Lear. In outrage, Lear swallows the bait, as it were, reacting with a sense of strangulation and smothering. Symbolically, if Kent is being tied by the legs, Lear is tied by the neck, like bears and dogs.

The fifth is castle, heath, and hovel. King Lear experiences one of his great moments of enlargement, a moment in which Lear widens his spiritual horizon and assumes the responsibilities for common humanity. Only now does Lear's suffering become an instance of all suffering. Now his pain is made one with the world's pain. Lear's growing spirit and widened sense may be traced in geographical symbolism. Lear's progress has been from castle to heath, and presently, to hovel. These three represent three major attitudes attending in Lear's heart. In the castle, Lear was proud, blindly proud and willful. On the heath, he experiences heart-struck injuries of pain and suffering when Lear feels Goneril 
and Regan's filial ingratitude and cruelty. On the heath or outdoors itself becomes symbolic, a revelation of the truth of man's humanity. The third attitude contending in Lear's heart is humility, represented by the low hovel that requires stooping when one enters in it.

The sixth is clothes. Despite his personal suffering, Gloucester is acutely aware of the suffering of others. Gloucester drove Edgar to nakedness; now he will unknowingly clothe his disinherited son. Clothing, in this case, is a symbol of charity. The seventh is music and medicine. The imagery of music and medicine prepares us for the awakening and recovery of King Lear. When the sphere of the universe were in order, then it was believed that music was heard. Thus, music, the symbol of harmony and peace, anticipates a return to health and sanity, to love and reunion. A second image, perhaps the most important, is medicine. Here physical medicine represents spiritual healing, and Cordelia herself is the medicine. The only place restoration can hang its medicine is on Cordelia's lips, the same lips that originally told Lear the truth "Nothing, my lord," and now will restore Lear to sanity with a kiss of love.

The eight is wheel. The wheel, in this regard, represents the up and down of chronicle of life. For Edgar and Edmund, the wheel has come full circle. The final relationship of these brothers is purely melodramatic. The good Edgar, long on the bottom of the wheel of fortune, is at last on top; and the evil Edmund, long in the ascendancy, ends up at the bottom. Formerly, Edmund becomes an honorable man; he gets high position, has lived in the castle and to be a rich man for a long time but Edgar becomes no one, a beggar, has lived in the hovel, and has nothing. But now' Edgar can defeat Edmund. Clearly, the wheel of fortune is also suggested as the wheel of Nemesis or of justice.

Meanwhile, macrocosm is the universe, nature and any great world which covers all things out of microcosm. Macrocosm includes sun, moon and other orbs, storm, rain, thunder and lightning, earth, air, fire and water, insanity, death, hell and heaven. The first is the sun, the moon and the other orbs. The sun is a symbol of bright life; the moon is the symbol of peaceful life created by Hecate in Greek Mythology and; other orbs represent the beautiful world. They, in broadest 
sense, represent the light of heaven. In the name of the sun, the moon and all the other orbs, Lear foully disclaims all his paternal care and banishes Cordelia. Without realizing it, he calls on the lights of heaven to witness his dark deed, not Cordelia's supposed crime. The sun, the moon, and other orbs may control our existence; but despite such fatalism, they, in turn, are controlled by the power of love. The second is storm, rain, thunder and lightning. Storm, rain, thunder and lightning are four things which often come in the same time. Psychologically, the storm is Lear's spirit storming, a massive emotional relief in which Lear cries out in literate outrage. Symbolically, the storm expresses a double judgment and a double world. Judgmentally, the tempest expresses a judgment on Lear as much as it does Lear's judgment on the world. Meanwhile, thunder and lightning rebuke Lear's follies as much as he rebukes Goneril and Regan's evils. Thus, the storm, thunder and lightning are only naturalistic phenomena but the three elements may be interpreted as the rage of nature over the bad deeds of children towards their parents. They are also the direct reward over the unjust action of a father, Lear, to the real obedient daughter, Cordelia.

The third is the earth, air, fire and water. The storm represents the great anger of Lear to his daughters which cause the disharmony of nature and a chaos of the fretful elements. The elements of nature consisting of the earth, air, fire and water are in radical disharmony; each attacking the other because of the causal false. The earth as a home of human being is destroyed by the storm and rain. Fire symbolizes Lear's anger. God punishes Lear who has sold love and banished Cordelia from England by sending big storms and big rain to destroy earth as a symbol of life. The water symbolizes passion but it may also suggest purification which means to purify Lear's sin and bad deeds he has done. In addition, the air represents freedom from oppressive situation. Having met Cordelia, Lear feels happy because he gets freedom from the cruel daughters, Goneril and Regan and finds new air to build bright life in his old age.

The fourth is the Insanity. After being banished by his daughters Goneril and Regan in the heath in the storm and rain, longer and longer Lear becomes frustrated and insane. The insanity of Lear is the symbol of judgment when he 
banishes Cordelia. Lear's loss of sanity is now an inescapable punishment for his earlier loss of reason. Had Lear properly used his reason in recognizing Cordelia's love, he would not now have lost his reason in suffering Goneril and Regan's cruel ingratitude. The punishment of madness is the cost of the abuse of reason. Because of his unusual clothes and attitude, Lear thinks that Tom is also the insane. Gloucester also considers that Tom is the insane. But Tom's insane attitude and clothes are only disguising and it is his only way to understand the world more.

The fifth is the death. All human beings will die and death is natural tragedy. In this play we see that all the characters die in different causes. After knowing the cruel deeds done by Cornwall, Regan, and Goneril who have banished Lear and stabbed Gloucester's eyes, the courageous servant dares to oppose them. He not only rebels against his master but also kills Cornwall. In return of his bravery to kill Cornwall, Regan stabs the servant in the back. The servant dies in the place. In certain time, Edgar as poor Tom emerges as the militant hero. He saves his father a second time, from being murdered instead of from suicide. Using a peasant accent and a heavy cudgel, he kills the serviceable villain Oswald, Goneril's servant. Meanwhile, Gloucester dies of the sick after the long misery and torture, almost literally, of a broken heart. Similarly, the dirty lives and the decayed souls of the sisters Goneril and Regan finally come to a violent, self-destructive end. Each of them falls in love with the same man, Edmund. Because of her jealous passion for Edmund, Goneril poisons Regan. But her husband, the duke of Albany, discovers her deed and puts her in the prison where she soon commits suicide, out of empty frustration. Both Goneril and Regan die for nothing. Cordelia also finds bad fortune. The armies which Goneril and Regan have sent out under the command of Edmund, the bad earl of Gloucester, are successful to defeat her army. Cordelia is then taken to prison but soon afterwards Edmund hangs her. She dies and her death is held in the higher extremity of love. After the death of Cordelia, Lear becomes frustrated. Owing to his despair, old age and his misery, Lear does not live long after his kind child's death. Before the king dies, the good earl of Kent tries to tell him that it is he who 
has followed him under the name of Caius. This faithful servant to the king, old and full of grief, dies soon after his master. Then, the bad earl of Edmund is killed in a single fight with his brother, Edgar who has planned to take revenge for his betrayal to his father. So all the characters in the play die, and the story ends with them.

The sixth is the hell and heaven. Hell and heaven, in this regard, represent the judgment of God given to the human beings. Hell symbolizes the justice which punishes the guilty. Although Lear is putting Goneril and Regan on trial for their sins against him, he himself is on trial and under punishment for his sin against Cordelia. Lear is being punished for his sins by the sins of others; how he treated Cordelia is repaid by the treatment of Goneril and Regan. Hell also suggests the love relationship between Goneril and Edmund. The world of Goneril and Edmund is symbolically hell is that there moral values are turned the wrong side out. Meanwhile, Heaven represents the happy and peaceful life Gloucester hopes to be given to Edgar. During in the heath under the good treatment of Poor Tom, Gloucester soon realizes that Edmund has betrayed him. He asks the Heavens to make Edgar happier by making himself more wretched. The word "Heaven" is also used to express Cordelia's true love to her father, King Lear. The imagery used here to describe Cordelia establishes her functional role as a forgiving angel. Her tears and eyes are divinely described as the holy water from her heavenly eyes. Water becomes the major symbol of purification and regeneration. In Cordelia's tears Lear will find forgiveness and redemption. Cordelia's chief qualification for angelic divinity is her absolute lack of any hate, revenge, or vindictiveness toward her father who has banished her and given her nothing.

\section{REFERENCES}

Craig, W.J. 1990. The Complete Works of William Shakespeare. London: Henry Pordes.

Elizabeth and Tom Burns (Ed). 1973. Sociology of Literature and Drama. Middlesex, England: Penguin Books Inc. 
Ford, Boris. 1960. The Age of Shakespeare. Middlesex: Penguin Book Ltd.

Hornby, AS. 1974. Oxford Advance Learner's Dictionary of Current English. London: Oxfor University Press.

Hawkes, Terence. 1977. New Accents Structuralism and Semiotics. London: Methuen \& Co. Ltd.

Jones, Jr. Edwards H. 1968. Outline of Literature. New York: The Macmillan Company.

Liberman, M. M. and Edward E. Foster. 1968. A Modern Lexicon of Literary Terms. Illinois: Scott, Foresman and Company.

Main, William W. 1962. The Tragedy of King Lear. New York: The Odyssey Press Inc.

Reaske, Christopher Russell. 1966. How To Analyze Drama. New York: Monarch Press.

Shipley, T. Joseph. 1962. Dictionary of World Literature. New Jersey: Littlefield, Adams \& Co.

Swingewood, Alan and Diana Laurenson. 1970. Sociology of Literature. London: Granada Publishing Limited. 